\title{
Conclusiones leídas en el acto de clausura de las II Jornadas de «Fuentes Orales y Gráficas» sobre Los africanos en España (25-26 de noviembre de 1992)
}

\author{
VÍCTOR MORALES LEZCANO \\ (Coordinador de las Jornadas)
}

1) Estas segundas jornadas (que, en rigor, son las terceras) se inscriben en la trayectoria académica del "Seminario de Fuentes Orales y Gráficas» del Departamento de Historia Contemporánea (Facultad de Geografía e Historia de la UNED).

2) Ya en las jornadas anteriores el tema de «Emigración/Inmigración en la España contemporánea (1940-1990)" había hecho acto de aparición ocasional. El hecho de haber realizado un trabajo de campo sobre "Marroquíes y guineanos en Madrid" a partir de fuentes orales para el Instituto de Migraciones (Ministerio de Trabajo) (1991), contribuyó a que se canalizara el objetivo de estas últimas jornadas hacia Los africanos en España.

3) En ellas se ha querido recoger la "transición" social que se ha operado en España de la etapa de país emisor de emigrantes a presunta tierra de acogida de inmigrantes económicos. Las dos comunidades que han sido privilegiadas - marroquies y guineanos-, no han impedido que otras varias, como la argelina y senegalesa, fueran también tenidas en consideración en las investigaciones de ponentes, comentarios de moderadores de sesiones y público inscrito para el seguimiento de las jornadas.

4) Las ponencias han recurrido a un abanico de fuentes - de "espejos»- y de la problemática inmigratoria en España, siempre desde un prisma interdisciplinar. No han faltado a la cita historiadores del mundo 
actual, sociológicos, antropólogos, juristas y profesionales de los medios de comunicación. Todos ellos han abrevado en fuentes de alcance social considerable - prensa, fotografía, cine y, muy particularmente, "relatos de vida" procedentes de inmigrantes africanos en Madrid, Canarias, Ceuta y Melilla, Barcelona y otros puntos geográficos de los más transitados en España por los inmigrantes económicos.

5) La exposición de libros atinentes a los tres extremos relacionados en las jornadas Fuentes Orales y Gráficas, e Inmigración extranjera en España-, y la sesión de cine-forum que coronó esas jornadas (actividades a las que contribuyeron gentilmente el Instituto de Migraciones, el Centro de Arte Reina Sofía y el Consejo Británico), ayudaron a la ambientación del núcleo académico que gobernó la experiencia durante dos días de celebración.

6) Las recomendaciones a que se apuntan en esta hora final de las jornadas, pueden resumirse en los extremos siguientes:

a) Publicación de las ponencias y debates (grabados en cinta magnética) en forma de coedición UNED/Instituto de Migraciones;

b) posibilidad de consolidar el «Seminario de Fuentes Orales y Gráficas" mediante su instalación en un futuro despacho del edificio de Biblioteca de la UNED y apertura de una sub-especialización en el tema de "Migraciones en la España del siglo XX";

c) realización de un Curso de matrícula abierta a distancia (o master) centrado en el objeto de estudio abordado en esta ocasión, con participación inter-departamental;

d) favorecimiento de las producciones audio-visuales del CEMAV dedicadas a las "Migraciones en la España del siglo XX». 